\title{
Antimycobacterial Plant Terpenoids
}

\author{
Charles L. Cantrell ${ }^{1, *}$, Scott G. Franzblau², Nikolaus H. Fischer ${ }^{3}$ \\ ${ }^{1}$ U.S. Department of Agriculture, Agricultural Research Service, National Center for Agricultural Utilization Research, Peoria, Illinois, USA \\ ${ }^{2}$ Institute for Tuberculosis Research, College of Pharmacy, University of Illinois at Chicago, Chicago, Illinois, USA \\ ${ }^{3}$ Department of Pharmacognosy, Research Institute of Pharmaceutical Sciences, School of Pharmacy, The University of Mississippi, Oxford, \\ Mississippi, USA
}

Received: June 13, 2001; Accepted: July 10, 2001

\begin{abstract}
Tuberculosis (TB), mainly caused by Mycobacterium tuberculosis, is the leading killer among all infectious diseases worldwide and is responsible for more than two million deaths annually. For over thirty years no antitubercular agents with new mechanisms of action have been developed. The recent increase in the number of multi-drug resistant clinical isolates of M. tuberculosis has created an urgent need for the discovery and development of new antituberculosis leads. This review covers recent reports on plant-derived terpenoids that have demonstrated moderate to high activity in in vitro bioassays against $M$. tuberculosis. In this review, mono-, sesqui-, di- and triterpenes, and sterols, their structural analogs and semisynthetic derivatives will be discussed, with particular emphasis on the structural features essential for antimycobacterial activity.
\end{abstract}

Key words: Terpenoids, Mycobacterium tuberculosis, antituberculosis, tuberculostatic, antimycobacterial.

\section{Introduction}

It is estimated that one-third of the world's population is infected with the tubercle bacillus (1). While only a small percentage of infected individuals will develop clinical tuberculosis, each year there are approximately eight million new cases and two million deaths. M. tuberculosis is thus responsible for more human mortality than any other single bacterial species. The HIV pandemic has exacerbated the problem by providing a large reservoir of highly susceptible individuals (2).

A number of efficacious antitubercular agents were discovered in the late 1940's and 1950's with the last, rifampin, introduced in the 1960's (3), (4). These agents have reasonable efficacy and when used in combination should preclude the development of drug resistance. The use (or in most cases misuse) of these drugs has lead over the years to an increasing prevalence of multiple-drug resistant (MDR) strains and there is now an urgent need to develop new effective agents (5), (6).

There have been a number of practical obstacles to the development of new anti-TB agents, among them a lack of econom-

Planta Med 67 (2001) 685-694

(c) Georg Thieme Verlag Stuttgart · New York ISSN: 0032-0943 ic incentive due to the predominance of disease in the developing world. The very slow growth and highly contagious nature of $M$. tuberculosis have also served to discourage the drug discovery effort.

Nonetheless, several drugs with interesting anti-TB activity have been identified in the past few years; three such compounds are the rifamycins. Rifabutin, with less P450 activating activity than rifampicin, has activity against a small percentage of rifampin-resistant strains (7), (8) and is active clinically (9), (10), (11), (12). Rifapentene provides a much longer serum half-life and thus holds the promise of allowing for intermittent dosing but exhibits complete cross-resistance with rifampin (13). KRM-1648 appears to be the most potent among the rifamycins and has demonstrated activity in phase II trials in tuberculosis (14); however, it also exhibits partial cross-resistance with rifampin. Fluoroquinolones such as ofloxacin and levofloxacin have demonstrated clinical activity (15), (16), (17), (18); however, the recently approved (in the U.S.A. for non-TB respiratory indications) moxifloxacin appears to be the most active flouroquinolone against $M$. tuberculosis in vitro and in the mouse (19), (20), (21). Two members of a new class of antimicrobials, the oxazolidinones, showed modest in vivo activity against $M$. tuberculosis (22). Finally a nitroimidazopyran has demonstrated interesting in vitro and in vivo activity (23). While all of these compounds show potential, none have yet to demonstrate activity in clinical trials (with the exception of KRM-1648 and the older quinolones), thus there continues to be a need to identify new agents.

The following review surveys the literature for plant-derived terpenoids that have demonstrated moderate to significant biological activity against $M$. tuberculosis. It covers active compounds of five major groups of terpenoids: monoterpenes, sesquiterpenes, diterpenes, triterpenes, as well as phytol and its derivatives and structural analogs. Nearly all of the compounds discussed were screened using the BACTEC 460 system (24), (25) except where indicated otherwise. Compounds that did not demonstrate a minimum inhibitory concentration (MIC) of $64 \mu \mathrm{g} / \mathrm{ml}$ or lower and were unrelated to active terpenoids, have been omitted. Comparisons between chemical structures and their biological activities must be treated with caution, especially when different bioassay techniques have been used. 
Table 1 Minimum inhibitory concentrations (MICs) of selected plant terpenoids against M. tuberculosis $\left(\mathrm{H}_{37} \mathrm{Rv}\right)$

\begin{tabular}{lll}
\hline Compound Class & Source & MIC $(\mu \mathrm{g} / \mathrm{ml})^{\mathrm{a}}$
\end{tabular}

\section{Antituberculosis Drugs \\ isoniazid \\ rifampin \\ streptomycin \\ ethambutol \\ pyrazinamide}

\section{Monoterpenes}

citronellol (1)

nerol (2)

geraniol (3)

\section{Sesquiterpenes}

costunolide (4)

$11 \beta \mathrm{H}$-dihydrocostunolide (5)

parthenolide (6)

$11 \beta \mathrm{H}$-dihydroparthenolide (7)

1,10-epoxycostunolide (8)

1,10-epoxydihydrocostunolide (9)

1,10-epoxyparthenolide (10)

1,10-epoxydihydroparthenolide (11)

$\alpha$-cyclocostunolide (12)

santamarine (13)

$11 \beta \mathrm{H}, 13$-dihydrosantamarine (14)

$\beta$-cyclocostunolide (15)

reynosin (16)

$11 \beta \mathrm{H}, 13$-dihydroreynosin (17)

$\alpha$-santonin (18)

reynosin triol derivative (19)

11,13-dihydro triol of reynosin (20)

santamarine triol derivative (21)

dehydrocostuslactone (22)

7-hydroxydehydrocostuslactone (23)

zaluzanin C (24)

dehydrocostuslactone, $4 \alpha(15)$-epoxide (25)

dehydrocostuslactone, $10 \beta(14)$-epoxide (26)

dehydrocostuslactone, $10 \alpha(14)$-epoxide (27)

dehydrocostuslactone, $4 \beta(15), 10 \alpha(14)$-diepoxide (28)

dehydrocostuslactone, $4 \alpha(15), 10 \alpha(14)$-diepoxide (29)

dehydrocostuslactone, $4 \alpha(15), 10 \beta(14)$-diepoxide (30)

micheliolide (31)

pumilin (32)

damsin (33)

deacetylconfertiflorin (34)

confertiflorin (35)

deacetylisoconfertiflorin (36)

parthenin (37)

tenulin (38)

peruvin (39)

peruvin acetate $(\mathbf{4 0})$

burrodin (41)

aromaticin (42)

alantolactone (43)

isoalantolactone (44)

encelin (45)

1,2-dehydro-3-epi-isotelekin (46)

ivalin (47)

$11 \alpha H$,13-dihydroisoalantolactone (48)

isoalloalantolactone (49)

alloalantolactone $\mathbf{5 0}$

3-oxoalloalantolactone (51)

$4 \alpha$-epoxyisoalantolactone (52)

$5 \alpha$-epoxyalantolactone (53)
Sigma-Aldrich Co. $\quad 0.05$

Sigma-Aldrich Co.

Sigma-Aldrich Co.

2.0

3.8

Sigma-Aldrich Co.

100

Sigma-Aldrich Co.

Sigma-Aldrich Co.

Sigma-Aldrich Co.

64

64

Saussurea lappa

nthetic analog

Magnolia grandiflora

Ambrosia artemisiifolia

synthetic analog

synthetic analog

synthetic analog

synthetic analog

synthetic analog

Ambrosia confertiflora

Sonchus hierrensis

synthetic analog

Ambrosia confertiflora

synthetic analog

Artemisia ramosa

$-$

$-$

Saussurea lappa

Podachenium eminens

Zaluzania triloba

synthetic analog

synthetic analog

synthetic analog

synthetic analog

synthetic analog

synthetic analog

Berlandiera texana

Ambrosia maritima

Ambrosia confertiflora

Ambrosia confertiflora

synthetic analog

Parthenium hysterophorus

Helenium amarum

Ambrosia peruviana

ynthetic analog

Ambrosia dumosa

Helenium aromaticin

Inula helenium

Inula helenium

Montanoa speciosa

Montanoa speciosa

Iva imbricata

Inula helenium

Rudbeckia mollis

Rudbeckia subtomentosa

Rudbeckia subtomentosa

synthetic analog

synthetic analog 
Table 1 cont.

\begin{tabular}{|c|c|c|c|}
\hline $\begin{array}{l}\text { Compound Class } \\
\text { Name }\end{array}$ & Source & $\operatorname{MIC}(\mu \mathrm{g} / \mathrm{ml})^{\mathrm{a}}$ & Reference \\
\hline 11,13-dihydroxyalantolactone (54) & synthetic analog & $>128$ & $(31)$ \\
\hline 6-epi-deacetyllaurenobiolide (55) & Montanoa grandiflora & 16 & $(45)$ \\
\hline 4,5-epoxy-6-epideacetyllaurenobiolide (56) & synthetic analog & 16 & $(26)$ \\
\hline curcuphenol (57) & Euthamia leptocephela & 16 & (Robbs, S.L., 1997 unpublished) \\
\hline nerolidol (58) & Magnolia acuminata & 32 & $(26)$ \\
\hline farnesol (59) & Sigma-Aldrich Co. & 8 & $(27)$ \\
\hline \multicolumn{4}{|l|}{ Diterpenes } \\
\hline sandaracopimara-8(14)-15-diene-7 $\alpha, 18$-diol (60) & Tetradenia riparia & $25-100^{d}$ & $(33)$ \\
\hline sandracopimaric acid (61) & Juniperus excelsa & $15.0^{\mathrm{b}}$ & (34) \\
\hline sclareol (62) & - & $6.0^{\mathrm{b}}$ & (34) \\
\hline 12-demethylmulticauline (63) & Salvia multicaulis & $0.46^{c}$ & $(32)$ \\
\hline multicaulin (64) & Salvia multicaulis & $5.6^{c}$ & $(32)$ \\
\hline 12-demethylmultiorthoquinone (65) & Salvia multicaulis & $1.2^{\mathrm{c}}$ & $(32)$ \\
\hline multiorthoquinone $(66)$ & Salvia multicaulis & $2.0^{c}$ & $(32)$ \\
\hline 12-methyl-5-dehydrohorminone (67) & Salvia multicaulis & $1.2^{\mathrm{c}}$ & $(32)$ \\
\hline 12-methyl-5-dehydroacetylhorminone (68) & Salvia multicaulis & $0.89^{c}$ & $(32)$ \\
\hline salvipimarone $(69)$ & Salvia multicaulis & $7.3^{c}$ & $(32)$ \\
\hline 9,12-cyclomulin-13-ol (70) & Azorella madreporica & 20 & $(35)$ \\
\hline juniperexcelsic acid (71) & Juniperus excelsa & $14.4^{b}$ & (34) \\
\hline
\end{tabular}

\section{Triterpenes}

ergosterol-5,8-endoperoxide (72)

ergosterol-5,8-endoperoxide acetate (73)

ergosterol (74)

$12 \beta$-hydroxykulactone (75)

6 $\beta$-hydroxykulactone (76)

kulonate (77)

(24R)-24,25-epoxycycloartan-3-one (78)

$(3 \beta, 24 R)-24,25$-epoxycycloartan-3-ol (79)

$(3 \beta, 24 R)-24,25$-epoxycycloartan-3-ol acetate $(\mathbf{8 0})$

(23R)-3-oxolanosta-8,24-dien-23-ol (81)

compound $\mathbf{8 2}$

fusidic acid (83)

zeorin (84)

$7 \beta$-acetyl-22-hydroxyhopane (85)

$7 \beta, 22$-dihydroxyhopane (86)

oleanolic acid (87)

erythodiol (88)

3-epioleanolic acid (89)

oleanonic acid (90)

lupeol (91)

betulinic acid (92)

betulin (93)

epi-betulinic acid (94)

lupeol acetate (95)

lupenone (96)

3-hydroxynorlupen-2-one (97)

3-acetoxynorlupen-2-one (98)

ursolic acid (99)

uvaol (100)

pomolic acid (101)

pomolic acid acetate (102)

tormentic acid (103)

2-epi-tormentic acid (104)

euscaphic acid (105)

niga-ichigoside F1 aglycone (106)
Ajuga remota

synthetic analog

Sigma-Aldrich Co.

Melia volkensii

Melia volkensii

Melia volkensii

Borrichia frutescens

Borrichia frutescens

Borrichia frutescens

Borrichia frutescens

synthetic analog

Sigma-Aldrich Co.

Sarmienta scandens

Sarmienta scandens

Sarmienta scandens

Baccharis patagonica

Baccharis patagonica

Junellia tridens

Junellia tridens

Chuquiraga ulicina

$-$

Monttea aphylla

Chuquiraga ulicina

Chuquiraga ulicina

Chuquiraga ulicina

Chuquiraga ulicina

Aspidosperma quebracho-blanco

-

Acaena pinnatifida

Acaena pinnatifida

Acaena pinnatifida

Acaena pinnatifida

Acaena pinnatifida

Acaena pinnatifida

Lucas volkensii

synthetic analog

synthetic analog

synthetic analog
1

8

$>128$

16

4

16

8

8

$>128$

64- 128

$>128$

4

8 e

$>128^{\mathrm{e}}$

$>128^{\mathrm{e}}$

$64^{\mathrm{e}}$

$64^{\mathrm{e}}$

16

16

$64^{\mathrm{e}}$
$32^{\mathrm{e}}$

$32^{\mathrm{e}}$

$64^{\mathrm{e}}$

$>128^{\mathrm{e}}$

$>128^{\mathrm{e}}$

$>128^{\mathrm{e}}$

$>128^{\mathrm{e}}$

$32^{\mathrm{e}}$

$32^{\mathrm{e}}$

$64^{\mathrm{e}}$

$32^{\mathrm{e}}$

$32^{\mathrm{e}}$

$>128^{\mathrm{e}}$

$128^{\mathrm{e}}$

$>128^{\mathrm{e}}$

(25), (46)

Phytol, derivatives, and analogs

(E)-phytol (107)

(E)-phytyl acetate (108)

(E)-phytol methyl ether (109)

phytyl amine (110) 
Table 1 cont.

\begin{tabular}{|c|c|c|c|}
\hline $\begin{array}{l}\text { Compound Class } \\
\text { Name }\end{array}$ & Source & $\operatorname{MIC}(\mu \mathbf{g} / \mathrm{ml})^{\mathrm{a}}$ & Reference \\
\hline phytyl amine (110) & synthetic analog & 32 & (26) \\
\hline phytyl diisopropylamine (111) & synthetic analog & 64 & (26) \\
\hline (Z)-phytol (112) & Sigma-Aldrich Co. & 2 & (27) \\
\hline$(3 R, S, 7 R, 11 R)$-phytanol (113) & synthetic analog & 2 & (27) \\
\hline (E)-phytol epoxidation epimers (114) & synthetic analog & 8 & (27) \\
\hline$(3 R, S, 7 R, 11 R)$-phytanic acid (115) & synthetic analog & $>128$ & $(27)$ \\
\hline 2-phytylphenol (116) & synthetic analog & 32 & $(26)$ \\
\hline phytantriol (117) & Sigma-Aldrich Co. & 16 & (26) \\
\hline 2-hexadecanol (118) & Sigma-Aldrich Co. & 8 & (26) \\
\hline
\end{tabular}

a Biological activity determined using BACTEC radiorespirometric bioassay except where noted otherwise.

${ }^{\mathrm{b}}$ Biological activity determined using disc-diffusion method.

' Biological activity determined using broth microdilution method.

${ }^{\mathrm{d}}$ Biological activity determined by conventional proportion method. Clinical isolates of $M$. tuberculosis were used in the bioassay.

e Concentration reported in $\mu \mathrm{M}$.

\section{Monoterpenes}

Due to the small number of monoterpenes with reported biological data and their structural similarity to phytol and its analogs, a more detailed structure-activity analysis will be discussed together with the results on phytol. It should be briefly pointed out, however, that among the open-chain monoterpenes, citronellol (1), nerol (2), and geraniol (3) gave MICs of 64,128 and $64 \mu \mathrm{g} / \mathrm{ml}$, respectively (Table 1) (26), (27). Compounds 2 and 3 represent respective $Z$ - and $E$-isomers, and 1 being saturated at $C-2$; this suggests that the presence of a C-2 double bond has only minor influences upon the activity.

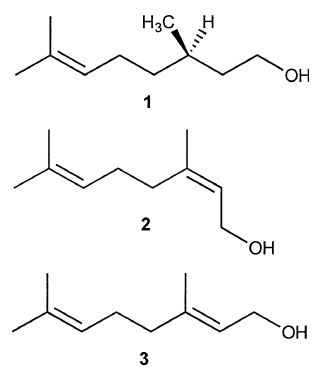

\section{Sesquiterpenes}

Among the over fifty sesquiterpenes, mainly sesquiterpene lactones of the germacranolide, guaianolide, and eudesmanolide type, tests resulted in MICs ranging from $2 \mu \mathrm{g} / \mathrm{ml}$ to $>128 \mu \mathrm{g} / \mathrm{ml}$. A series of $\alpha$-methylene- $\gamma$-lactone containing germacranolides showed MICs at or below $64 \mu \mathrm{g} / \mathrm{mL}$ (28). The relatively lipophilic costunolide (4) gave an MIC of $32 \mu \mathrm{g} / \mathrm{ml}$ while its 4-epoxide derivative, parthenolide (6), showed an increased activity against $M$. tuberculosis (MIC $16 \mu \mathrm{g} / \mathrm{ml}$ ). The 1(10)-epoxycostunolide (8) was less active than 4 and 6 with an MIC of $64 \mu \mathrm{g} / \mathrm{ml}$, suggesting that the position of the epoxide within the medium ring has a distinct influence on the activity. With the exception of the non-active diepoxide 1,10-epoxyparthenolide (10), all the sesquiterpene lactones in this series with an $\alpha$-methylene- $\gamma$-lactone moiety $(4,6,8,13,16$, 12 and 15) have activities with MICs at $64 \mu \mathrm{g} / \mathrm{ml}$ or below. In contrast, their $11 \beta \mathrm{H}, 13$-dihydro derivatives $(\mathbf{5}, \mathbf{7}, \mathbf{9}, \mathbf{1 4}$, and $\mathbf{1 7})$ as well as the sesquiterpenes obtained by reductive opening of the lactone ring $(\mathbf{1 9}, \mathbf{2 0}$, and $\mathbf{2 1}$ ) (29) showed no activity against $M$. tuberculosis at concentrations below $128 \mu \mathrm{g} / \mathrm{ml}$, suggesting that the presence of the exocyclic $\alpha$-methylene- $\gamma$ lactone moiety is essential, but not sufficient, for activity.<smiles>C=C1C(=O)O[C@H]2/C=C(\C)CC/C=C/CCC12</smiles>

$\mathbf{4} 11$ 5 11ßH, 13-dihydro<smiles>C=C1C(=O)O[C@H]2C1CCC1(CO1)C1OC1CCC2(C)C</smiles>
$10111 \mathrm{HH}, 13-$ dihydro<smiles>CC1=C2C3OC(=O)[C@@H](C)[C@H]3CCC2(C)C=CC1=O</smiles>
18<smiles>C=C(CO)[C@H]1CC[C@]2(C)[C@@H](O)CC=C(C)[C@H]2[C@H]1O</smiles>

21<smiles>C=C1C(=O)O[C@@H]2O[C@H]3C(=CCCC3(C)C)CCC12</smiles>
711ßH, 13-dihydro<smiles>C=C1C(=O)O[C@H]2C1CCC1(C)C(C)=CCC(Br)[C@@H]21</smiles>
$12 \mathrm{R}=\mathrm{H}$
$13 \mathrm{R}=\mathrm{O}$ $13 \mathrm{R}=\mathrm{OH}$ $14 \mathrm{R}=\mathrm{OH} ; 11 \beta \mathrm{H}, 13$-dihydro<smiles>C=C(CO)[C@H]1CC[C@]2(C)[C@@H](O)CCC(=C)[C@H]2[C@H]1O</smiles>

19

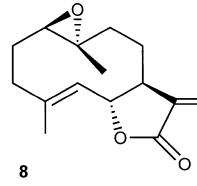

8
$911 \beta H, 13-$-ihydro

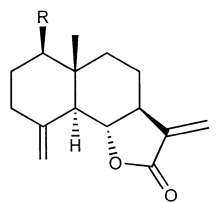

$15 \mathrm{R}=\mathrm{H}$

$16 \mathrm{R}=\mathrm{OH}$ $17 \mathrm{R}=\mathrm{OH} ; 11 \beta \mathrm{H}, 13-$ dihydro<smiles>C=C1CC[C@@H](O)[C@]2(C)CCC(C(C)CO)[C@H](O)[C@H]12</smiles>

Parthenolide, with an MIC of $16 \mu \mathrm{g} / \mathrm{ml}$, was the most active germacranolide tested and exhibited a higher MIC than costunolide (MIC $=32 \mu \mathrm{g} / \mathrm{ml}$ ). Moreover, 1(10)-epoxycostunolide (8) and the diepoxide $\mathbf{1 0}$, although both with an $\alpha$-methylene$\gamma$-lactone moiety and an epoxide at C-1(10), neither compound showed activity comparable with parthenolide (6). It has therefore been suggested that the higher antimycobacterial activity of parthenolide (6) may be due to the presence of two sites of alkylation, one site being the $\alpha$-methylene- $\gamma$-lac- 
tone moiety and the other site at $\mathrm{C}-10$, the electron deficient center being generated by a transannular cyclization with the $\mathrm{C}-1(10)$ double bond being the donor and the $\mathrm{C}-5$ epoxide the nucleophilic receptor (28).

A series of guaianolides screened against $M$. tuberculosis demonstrated MICs ranging from 2 to $>128 \mu \mathrm{g} / \mathrm{ml}$, with the lipophilic dehydrocostuslactone (22) (MIC of $2 \mu \mathrm{g} / \mathrm{ml}$ ) being the most active (30). Semi-synthetic mono- and diepoxide derivatives of $22(\mathbf{2 5 - 3 0})$, as well as its hydroxy analogs showed very distinct activity trends. Monoepoxides 25, 26, and 27 were more active than the more polar diepoxides $\mathbf{2 8}, \mathbf{2 9}$, and 30, which in turn were more active than the more polar hydroxy analogs 23 and 24. It has been suggested that the low MIC of $\mathbf{2 2}$ may be due not only to its exocyclic methylene lactone moiety but also to its lipophilic nature (30). This was supported by the decreased activity from $\mathbf{2 2}$ to the more polar monoepoxides via the diepoxides to the most polar hydroxy analogs 23 and 24. Micheliolide (31) (MIC $50 \mu \mathrm{g} / \mathrm{mL}$ ) holds a unique position, possibly due to the ability to undergo an intramolecular substitution involving the 1(10)-double bond as a nucleophilic donor and the C-4 hydroxy as a leaving group, thus allowing a double alkylation as in parthenolide $(\mathbf{6})$.

The pseudoguaianolides damsin (33), parthenin (37), and aromaticin (42) showed antimycobacterial activity with MICs of 32,64 , and $16 \mu \mathrm{g} / \mathrm{ml}$, respectively. This suggests that two alkylating sites within the molecule such as 42 , increase activity. Again, the more polar C-8 hydroxy (34) and acetoxy (35) analogs of 33 gave MICs of $128 \mu \mathrm{g} / \mathrm{ml}$, that is, much lower activity than 33, which may be due to the more polar nature of 34 and
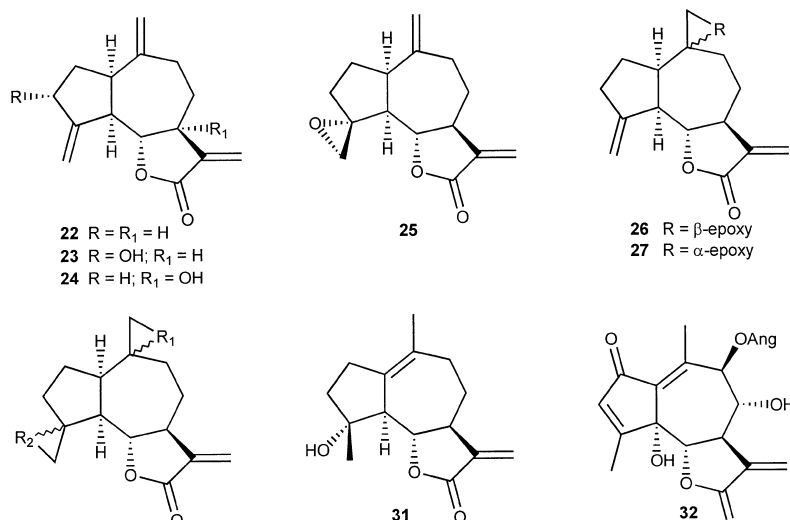

$28 R_{1}=\alpha$-epoxy; $R_{2}=\beta$-epoxy $29 R_{1}=\alpha$-epoxy; $R_{2}=\alpha$-epoxy $\begin{array}{ll}29 & R_{1}=\alpha \text {-epoxy; } R_{2}=\alpha \text {-epoxy } \\ 30 & R_{1}=\beta \text {-epoxy; } R_{2}=\alpha \text {-epoxy }\end{array}$
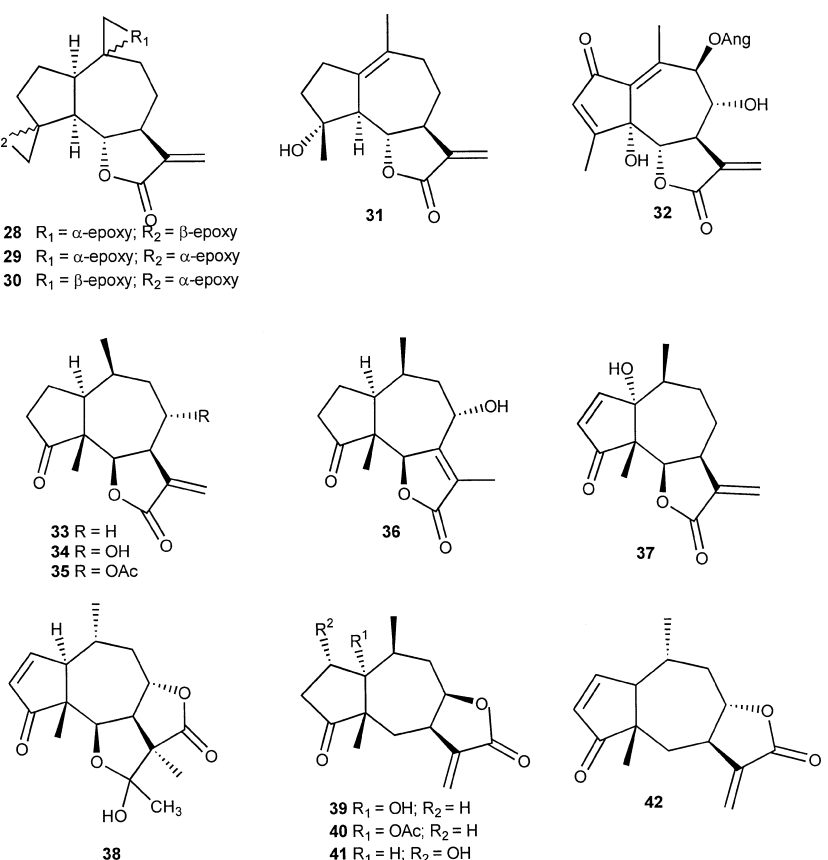
$40 \mathrm{R}_{1}=\mathrm{OAC} ; \mathrm{R}_{2}=\mathrm{H}$
$41 \mathrm{R}_{1}=\mathrm{H} ; \mathrm{R}_{2}=\mathrm{OH}$
35. Also, tenulin (38) differs from 42 in its absence of an $\alpha$ methylene- $\gamma$-lactone moiety. Consequently, its MIC of $128 \mu \mathrm{g} /$ $\mathrm{ml}$ further supports the necessity of this lactone group for significant activity.

Bioassay-directed investigations of Inula helenium and Rudbeckia subtomentosa resulted in the isolation of eudesmanolides, with MICs ranging from 8 to $>128 \mu \mathrm{g} / \mathrm{ml}$. Moderate activities were observed for alantolactone (43), isoalantolactone (44), $11 \alpha H, 13$-dihydroisoalantolactone (48), alloalantolactone (50), and 3-oxoalloalantolactone (51) (31). Compounds 43, 44, and 50 all gave MICs of $32 \mu \mathrm{g} / \mathrm{ml}$, while 48 and 51 were not active (MICs $>128$ and $128 \mu \mathrm{g} / \mathrm{ml}$, respectively). Stereoselective epoxidation of $\mathbf{4 3}$ gave the eudesmanolide $5 \alpha$-epoxyalantolactone (53) with an MIC of $8 \mu \mathrm{g} / \mathrm{ml}$ while oxidation of $\mathbf{4 3}$ with $\mathrm{OsO}_{4}$ resulted in the inactive dihydroxy derivative $\mathbf{5 4}$. Analogs of 44 include the monoepoxide 52, the C-2 hydroxy derivative 47, the conjugated ketone 45 , and alcohol 46 with MICs of $32,64,16$, and $32 \mu \mathrm{g} / \mathrm{ml}$, respectively.

As seen above with the various structural types of sesquiterpene lactones, the $\alpha$-methylene- $\gamma$-lactone moiety appears to be an essential, but not sufficient, structural requirement for significant activity. The necessity of the presence of an $\alpha$ methylene- $\gamma$-lactone group is supported by the moderate to high activity of $\alpha$-methylene- $\gamma$-lactone bearing sesquiterpenes, when compared with the inactive $11 \alpha H, 13$-dihydro derivatives with values of $128 \mu \mathrm{g} / \mathrm{ml}$ or higher. The presence of a second alkylating site, such as an $\alpha, \beta$-unsaturated carbonyl group and/or an epoxide function together with moderate to high lipophilicity, seems to enhance the in vitro antimycobac-<smiles>C=C1C(=O)OC2CC3(C)CCCC(C)C3=CC12</smiles>

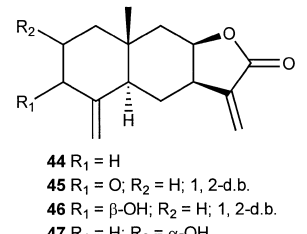<smiles>C=C1CCCC2(C)CC3OC(=O)C(C)C3CC12</smiles>
48<smiles>C=C1C(=O)OC2CC3(C)CCC=C(C)[C@H]3CC12</smiles>

49<smiles>C=C1C(=O)OC2CC3(C)CCCC(C)C3(O)C1C2O</smiles>
53<smiles>C=C1C(=O)OC2CC3(C)CCC(P)C(C)=C3CC12</smiles>
$50 R=H$
$51 R=O$<smiles>CC1CCCC2(C)CC3OC(=O)C(O)(CO)C3C=C12</smiles>
54<smiles>CC(C)=CCCC(C)c1ccc(C)cc1O</smiles><smiles>C=CC(C)(O)CCC=C(C)CCC=C(C)C</smiles>

58<smiles>CC(C)=CCC/C(C)=C/CC/C(C)=C/CO</smiles><smiles>C=C1C(=O)OC2C=C1C1C[C@@H]3C[C@H]3CCC[C@]1(C)C2</smiles>

52<smiles>C=C1C(=O)O[C@H]2C/C3=C/CC/C(C)=C/[C@H](O)C1C3C2</smiles>
55
59 
terial activity. For instance, encelin (45) is more active than 44 and $5 \alpha$-epoxyalantolactone (53), with an MIC of $8 \mu \mathrm{g} / \mathrm{ml}$, is significantly more active than its precursor 43 with an MIC of $32 \mu \mathrm{g} / \mathrm{ml}$.

The sesquiterpenes curcuphenol (57), nerolidol (58), and farnesol (59) gave MICs of 16,32 , and $8 \mu \mathrm{g} / \mathrm{ml}$, respectively. Compounds 58 and 59 are constitutional isomers differing in the positioning of the allylic alcohol. Due to the structural similarity of 57, 58, and 59 with phytol and its analogs, a more detailed discussion of their biological activities will follow later.

\section{Diterpenes}

A limited number of diterpenes have been tested for antituberculosis activity and some have demonstrated remarkable biological activities against $M$. tuberculosis with MICs below $1 \mu \mathrm{g} / \mathrm{ml}$. The most active among the diterpenes were recently reported by Ulubelen et al. from Salvia multicaulis, the norditerpenoid 12-demethylmulticauline (63) showing a remarkable MIC of $0.46 \mu \mathrm{g} / \mathrm{ml}$ and its C-12 methoxy analog, 64, with an MIC of $5.6 \mu \mathrm{g} / \mathrm{ml}$ (32). Similarly, the phenolic 0 -quinone (65) gave an MIC of $1.2 \mu \mathrm{g} / \mathrm{ml}$ while its C-2 methoxy analog had an MIC of $2.0 \mu \mathrm{g} / \mathrm{ml}$. Interestingly, the abietane diterpenoid 67 had an MIC of 1.2 while its C-12 acetate 68 was more active with an MIC of $0.89 \mu \mathrm{g} / \mathrm{ml}$ (32). Compounds 60 (33), 61 (34), 62 (34), 69 (32), 70 (35), and 71 (34) gave MICs of 25$100,15,6,7.3,20$, and $14.4 \mu \mathrm{g} / \mathrm{ml}$, respectively. Biological activities of the diterpene phytol, its derivatives and structural analogs will be discussed later.

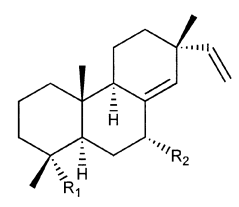

$60 \mathrm{R}_{1}=\mathrm{CH}_{2} \mathrm{OH} ; \mathrm{R}_{2}=\mathrm{OH}$ $61 R_{1}=\mathrm{COOH} ; \mathrm{R}_{2}=\mathrm{H}$<smiles>[R6]c1cc2c3c(ccc2c(C)c1C)C=C(C(C)C)C(=O)C3=O</smiles><smiles>COC1=C(C(C)C)C(=O)C2=C(C1=O)[C@@H](O)C=C1C(C)(C)CCC[C@]12C</smiles>

$67 \mathrm{R}=\mathrm{H}$
$68 \mathrm{R}=\mathrm{AC}$<smiles>CC(C)[C@H]1CC[C@H]2C34CC3[C@](C)(O)CC[C@](C)(CC[C@]12C)C4</smiles><smiles>C=CC(=C)CCC1C(=C)CCC2C1(C)CCC(OC(=O)O)[C@@]2(C)C(=O)O</smiles>

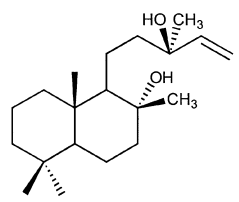<smiles>C=C[C@]1(C)C=C2C(O)CC3C(C)(C)C(=O)CC[C@]3(C)C2(O)C(=O)C1</smiles>

\section{Triterpenes and Sterols}

Numerous triterpenoids and sterols have been tested with MICs ranging from 1 to $>128 \mu \mathrm{g} / \mathrm{ml}$. Bioassay-guided investigations of active fractions from Ajuga remota led to the isolation of the most active triterpenoid, ergosterol-5,8-endoperoxide (72), with an MIC of $1 \mu \mathrm{g} / \mathrm{ml}$ (36). Acetylation of 72 provided the acetate, 73, with an MIC of $8 \mu \mathrm{g} / \mathrm{ml}$. In contrast, the parent compound, ergosterol (74), gave an MIC of $>128 \mu \mathrm{g} / \mathrm{ml}$. Compound 72 was prepared in a one step synthesis from commercially available ergosterol (74) (36) making it an ideal candidate for future structure-activity relationship studies. Within this set of ergosterol derivatives, it appears that the presence of a C-3-OH combined with the endoperoxide group is necessary for high antimycobacterial activity.

Bioactivity-guided investigations of Melia volkensii resulted in the isolation of $12 \beta$-hydroxykulactone (75), $6 \beta$-hydroxykulactone (76), and kulonate (77). Compounds 75 and 77 both had MICs of $16 \mu \mathrm{g} / \mathrm{ml}$ while compound 76 was more active with an MIC of $4 \mu \mathrm{g} / \mathrm{ml}$ (37). From this set of limited data, it appears that a hydroxy group at C-6 gives rise to higher activity than a C-12 hydroxy group. Based on the same activity of $\mathbf{7 5}$ and 77, there appears to be little or no effect on biological activity upon methanolysis of the lactone moiety.
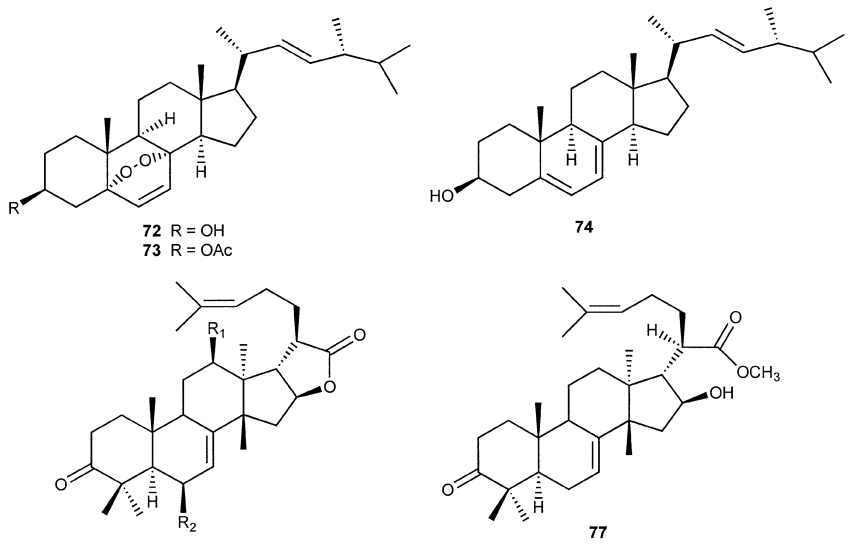

$75 \mathrm{R}_{1}=\mathrm{OH} ; \mathrm{R}_{2}=\mathrm{H}$
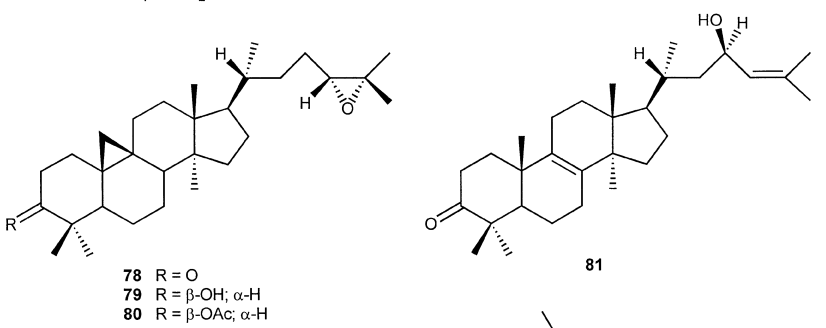<smiles>C[C@H](CCC(=O)O)[C@H]1CC[C@]2(C)C3CCC4C(C)(C)C(=O)CC[C@]45C[C@]35CC[C@]12C</smiles><smiles>CC(C)=CCC/C(C(=O)O)=C1/[C@H](O)C[C@]2(C)[C@H]3CCC4[C@@H](C)[C@@H](O)CC[C@]4(C)[C@H]3[C@H](O)C[C@]12C</smiles>

In another bioassay-guided investigation, Borrichia frutescens afforded a number of antimycobacterial cycloartanes (25). The most active of these compounds were (24R)-24,25-epoxycycloartan-3-one (78) and (3 $\beta, 24 R)$-24,25-epoxycycloartan-3- 
ol (79) with MICs of $8 \mu \mathrm{g} / \mathrm{ml}$, whereas the acetate 80 was inactive (MIC $>128 \mu \mathrm{g} / \mathrm{ml}$ ). Unsuccessful attempts to oxidize 79 to $\mathbf{7 8}$ resulted in the synthesis of the inactive degradation product 82 (MIC $>128 \mu \mathrm{g} / \mathrm{ml}$ ), and the isolate $\mathbf{8 1}$ gave an MIC of $64-128 \mu \mathrm{g} / \mathrm{ml}$. Correlations of structural features and the MICs of these five triterpenes suggest that the presence of the C-3 keto and/or $\beta$-hydroxy group, the cyclopropane ring and the epoxide moieties, as in $\mathbf{7 8}$ and $\mathbf{7 9}$, seem to play a major role in the in vitro antituberculosis activity. Both, the cyclopropane and epoxide functions are absent in 81, resulting in the loss of activity. Also, the loss of activity by acetylation of the $\mathrm{C}-3$ hydroxy group (MIC $>128 \mu \mathrm{g} / \mathrm{mL}$ ) strongly suggests that either a free hydroxy or a keto group at $\mathrm{C}-3$ is required for significant activity.

Several pentacyclic triterpenoids have been isolated with activities ranging from 8 to $>128 \mu \mathrm{M}$. The most active of these compounds was zeorin (84), isolated by bioassay-guided fractionation of Sarmienta scandens and shown to have an MIC of $8 \mu \mathrm{g} / \mathrm{ml}$ (38). 7 $\beta, 22$-Dihydroxyhopane (86) contains a $\beta$-hydroxy group at C-7 rather than an $\alpha$-hydroxy at C-6 in 84, resulting in a loss of activity ( $\mathrm{MIC}>128 \mu \mathrm{M}$ ). In addition, the C-7 acetoxy derivative of $\mathbf{8 6}, 7 \beta$-acetyl-22-hydroxyhopane (85), was inactive (38). 3-Epioleanolic acid (89) and oleanonic acid (90), which differ in the functional group present at $\mathrm{C}-3$, were both isolated from Junellia tridens and shown to have MICs of $16 \mu \mathrm{g} / \mathrm{ml}$ (39). Compound 89 contains an $\alpha$-hydroxy group at C-3 while 90 bears a ketone. Oleanolic acid 87 differs from 89 by the presence of a $C-3 \beta$ rather than an $\alpha$-hydroxy group, resulting in a less active derivative with an MIC of $64 \mu \mathrm{M}$. The dihydroxy analog of $\mathbf{8 7}$, erythrodiol (88), gave a similar MIC value of $64 \mu \mathrm{g} / \mathrm{ml}$. Similarly, ursolic acid (99) and betulinic acid (92) gave MIC values of $32 \mu \mathrm{M}$, identical to those of uvaol (100) and betulin (93) (38). In contrast to the results obtained when comparing the MICs of compounds 87 and $\mathbf{8 9}$, betulinic acid (92) with its $\beta$-hydroxy group at $\mathrm{C}-3$ is more active than its C-3 epimer, epi-betulinic acid (94) (MIC $64 \mu \mathrm{M}$ ). Also, re-

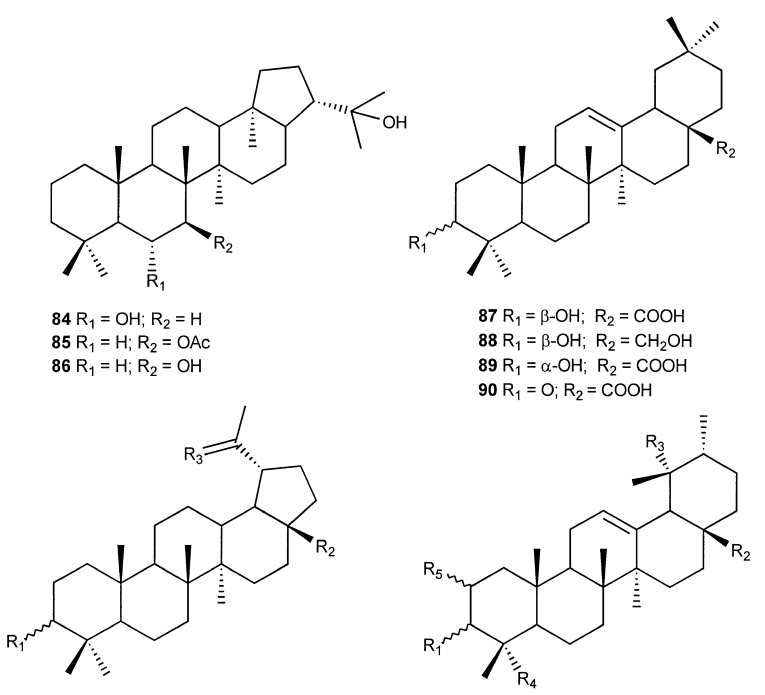

$91 \mathrm{R}_{1}=\beta-\mathrm{OH} ; \mathrm{R}_{2}=\mathrm{Me} ; \mathrm{R}_{3}=\mathrm{CH}_{2}$ $92 \mathrm{R}_{1}=\beta-\mathrm{OH} ; \mathrm{R}_{2}=\mathrm{COOH} ; \mathrm{R}_{3}=\mathrm{CH}_{2}$ 3 $\mathrm{R}_{1}=\beta-\mathrm{OH} ; \mathrm{R}_{2}=\mathrm{COOH}_{2} \mathrm{R}_{3}=\mathrm{CH}_{2}$ $93 \mathrm{R}_{1}=\beta-\mathrm{OH} ; \mathrm{R}_{2}=\mathrm{CH}_{2} \mathrm{O}, \mathrm{R}_{3}=\mathrm{CH}_{2}$ $94 \mathrm{R}_{1}=\alpha-\mathrm{OH} ; \mathrm{R}_{2}=\mathrm{COOH} ; \mathrm{R}_{3}=\mathrm{CH}_{2}$ $95 R_{1}=\beta-O A C ; R_{2}=M e ; R_{3}=C_{2}$ $96 R_{1}=O ; R_{2}=M e ; R_{3}=\mathrm{CH}_{2}$ $97 R_{1}=\beta-O H ; R_{2}=M e ; R_{3}=O$ $98 R_{1}=\beta-O A c ; R_{2}=M e ; R_{3}=0$
$99 \mathrm{R}_{1}=\beta-\mathrm{OH} ; \mathrm{R}_{2}=\mathrm{COOH} ; \mathrm{R}_{3}=\mathrm{H} ; \mathrm{R}_{4}=\mathrm{Me} ; \mathrm{R}_{5}=\mathrm{H}$ $100 \mathrm{R}_{1}=\beta-\mathrm{OH} ; \mathrm{R}_{2}=\mathrm{CH}_{2} \mathrm{OH} ; \mathrm{R}_{3}=\mathrm{H} ; \mathrm{R}_{4}=\mathrm{Me} ; \mathrm{R}_{5}=\mathrm{H}$ $101 \mathrm{R}_{1}=\beta-\mathrm{OH} ; \mathrm{R}_{2}=\mathrm{COOH} ; \mathrm{R}_{3}=\mathrm{OH} ; \mathrm{R}_{4}=\mathrm{Me} ; \mathrm{R}_{5}=\mathrm{H}$ $102 R_{1}=\beta-O A C ; R_{2}=C O O H ; R_{3}=O H ; R_{4}=M e ; R_{5}=H$ $103 R_{1}=\beta-O H ; R_{2}=C O O H ; R_{3}=O H ; R_{4}=M e ; R_{5}=\alpha-O H$ $104 \mathrm{R}_{1}=\beta-\mathrm{OH} ; \mathrm{R}_{2}=\mathrm{COOH} ; \mathrm{R}_{3}=\mathrm{OH} ; \mathrm{R}_{4}=\mathrm{Me} ; \mathrm{R}_{5}=\beta-\mathrm{OH}$ $105 \mathrm{R}_{1}=\alpha-\mathrm{OH} ; \mathrm{R}_{2}=\mathrm{COOH} ; \mathrm{R}_{3}=\mathrm{OH} ; \mathrm{R}_{4}=\mathrm{Me} ; \mathrm{R}_{5}=\alpha-\mathrm{OH}$ $106 \mathrm{R}_{1}=\beta-\mathrm{OH} ; \mathrm{R}_{2}=\mathrm{COOH} ; \mathrm{R}_{3}=\mathrm{OH} ; \mathrm{R}_{4}=\mathrm{CH}_{2} \mathrm{OH} ; \mathrm{R}_{5}=\alpha-\mathrm{OH}$ placement of the 3-hydroxy group of lupeol (91) with either an acetate or a ketone leads to complete loss of activity in lupeol acetate (95) and lupenone (96). A similar result was observed for the C-3 acetoxy derivative $\mathbf{8 0}$ when compared to 79. However, the 3-oxo derivative $\mathbf{7 8}$ gave the same MIC as $\mathbf{7 9}$ which is in contrast to the correlations mentioned above. Further complicating the situation was the observation that pomolic acid 3-acetate (102) was more active than pomolic acid (101) itself. Comparison of ursolic acid (99) with pomolic acid (101), tormentic acid (103), 2-epi-tormentic acid (104), euscaphic acid (105) and the aglycone of niga-ichigoside (106) showed that additional hydroxy groups in rings $\mathrm{A}$ and $\mathrm{E}$ can, in some cases, reduce activity (38). These conflicting results observed among the various groups of triterpenoids makes it difficult to predict structural requirements for antimycobacterial activity.

\section{Phytol, Derivatives and Analogs}

This group of open chain diterpenes covers phytol, its derivatives and structural analogs. Also included are the previously mentioned linear monoterpenes 1, 2, and 3 and diterpenes 57, 58, and 59. Within this set of structural analogs, all but two compounds showed MICs at or below $64 \mu \mathrm{g} / \mathrm{ml}$. One of the most active compounds in this series, (E)-phytol (107) (MIC $2 \mu \mathrm{g} / \mathrm{ml}$ ) was isolated from Lucas volkensii, using a bioassayguided fractionation (27). In addition, the analogs ( $Z$ )-phytol (112) and $(3 R, S, 7 R, 11 R)$-phytanol (113) demonstrated MICs of $2 \mu \mathrm{g} / \mathrm{ml}$, suggesting that the 2,3-double bond may not be essential for bioactivity. However, (E)-phytyl acetate (108) and (E)-phytol methyl ether (109) showed MICs of $16 \mu \mathrm{g} / \mathrm{ml} \mathrm{im-}$ plying that a free hydroxy group, as present in 107, is required for significant activity. Due to their structural and biosynthetic similarities to (E)-phytol, geraniol (3) and farnesol (59) were also tested against $M$. tuberculosis. The monoterpene alcohol geraniol had an MIC of $64 \mu \mathrm{g} / \mathrm{ml}$ while the more lipophilic farnesol with a 15-carbon chain gave a significant increase in activity with an MIC of $8 \mu \mathrm{g} / \mathrm{ml}$. Citronellol (1) and nerol (2) were tested due to their structural similarity to geraniol and gave MICs of 64 and $128 \mu \mathrm{g} / \mathrm{ml}$, respectively. The identical MICs of $64 \mu \mathrm{g} / \mathrm{ml}$ between geraniol and citronellol further support the observation above for phytol and its reduced isomer $(3 R, S, 7 R, 11 R)$-phytanol that the 2-double bond is not essential for biological activity. Additional derivatives and analogs tested include curcuphenol (57), nerolidol (58), phytylamine (110), phytyldiisopropylamine (111), (E)-phytol epoxidation epimers (114), (3R,S,7R,11R)-phytanic acid (115), 2-phytylphenol (116), phytantriol (117), and 2-hexadecanol (118) giving MICs of $16,32,32,64,8,>128,32,16$, and $8 \mu \mathrm{g} /$ $\mathrm{ml}$, respectively (27), (26). It is significant to note that a complete loss of activity is found when the C-1 hydroxy of $(3 R, S, 7 R, 11 R)$-phytanol (113) is oxidized to the carboxylic acid, $(3 R, S, 7 R, 11 R)$-phytanic acid (115), again suggesting that the free hydroxy is essential for high activity.

The most interesting observation among the above group of compounds is the relationship between the calculated log $\mathrm{P}$ values and the MIC. Higher lipophilicity generally results in higher antimycobacterial activity, within a series of structurally similar compounds. For example, the more lipophilic 20carbon phytol $(\log \mathrm{P}=8.66)$ is more active than the 15 -carbon farnesol $(\log \mathrm{P}=5.31)$ which is more active than the 10 carbon geraniol $(3)(\log \mathrm{P}=3.28)$. However, there appears to 


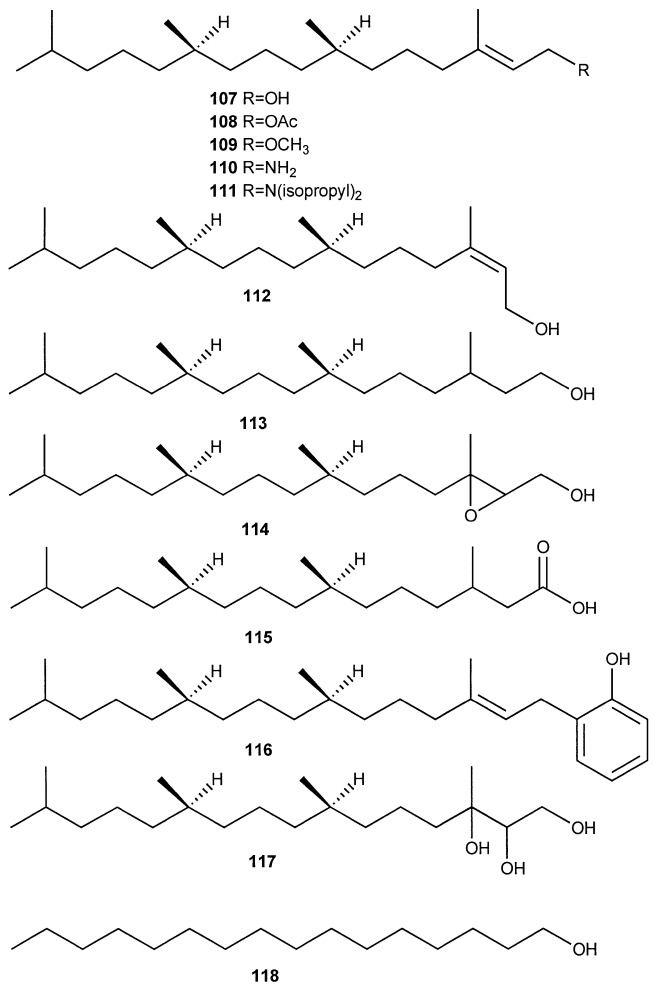

be a point at which further increasing the lipophilicity results in lower antimycobacterial activity (Fig. 1). Replacing the hydroxy of phytol with nitrogen containing functional groups strongly reduces activity in spite of an increase in lipophilicity. For example, replacing the hydroxy of phytol with a diisopropylamine as in $111(\log \mathrm{P}=11.14)$ results in a more lipophylic molecule that is less active. Figure $\mathbf{1}$ is a plot of calculated $\log \mathrm{P}$ values versus their respective MIC's, for a selected group of phytol derivatives and analogs.

\section{Conclusions}

A broad range of plant terpenoids from various classes have been evaluated for their in vitro antimycobacterial activity. The most active terpenoid presented in this review is the norditerpenoid 12-demethylmulticauline (63), isolated from the roots of Salvia multicaulis, with an MIC of $0.46 \mu \mathrm{g} / \mathrm{ml}$. It is more active than the first line tuberculosis drug ethambutol and nearly as active as rifampin. Further terpenoids with high activities are the sesquiterpene dehydrocostuslactone (22) with an MIC of $2 \mu \mathrm{g} / \mathrm{ml}$, the sterol ergosterol-5,8-endoperoxide (72) (MIC $1 \mu \mathrm{g} / \mathrm{ml}$ ), and (E)-phytol (107) with an MIC of $2 \mu \mathrm{g} / \mathrm{ml}$.

Distinct similarities between different classes of terpenes and the structural features important for high activity within each class have been observed. In each series it was shown that more lipophilic compounds are significantly more active than their more polar analogs. This was observed for the sesquiterpene lactone dehydrocostuslactone (22) which gave an MIC of $2 \mu \mathrm{g} / \mathrm{ml}$, when compared to its C -3 and C-7 hydroxy analogs, both with MICs of $>128 \mu \mathrm{g} / \mathrm{ml}$. Furthermore, higher MICs were found for the monoepoxide derivatives of $\mathbf{2 2}$, followed by even higher MICs of the diepoxides. Additional support for a correlation between lipophilicity and antimycobacterial activ-

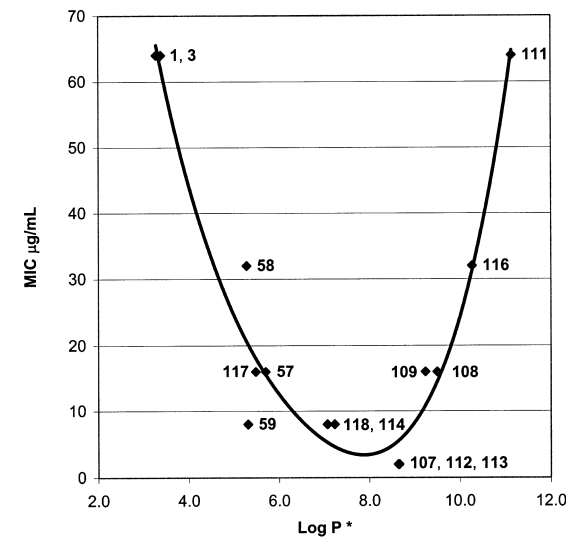

Fig. 1 The relationship between calculated Log $P$ values and antimycobacterial activity of phytol, its derivatives, and structural analogs. Plotted compounds include: $\mathbf{1}$, 3 , 57, 58, 59, 107, $108,109,111,112$, 113, 114, 116, 117, 118. Curve fitting was performed using a polynomial fourth order equation. ${ }^{*}$ Log $P$ values were estimated using ACD Labs Log P module (47).

ity was found in the (E)-phytol series in which the highest activity was observed for the least polar 20-carbon (E)-phytol (107) followed by the 15-carbon analog farnesol (59), which was more active than the more polar 10-carbon geraniol (3).

Among phytol (107), its acetate (108), and methyl ether ana$\log 109$, both derivatives gave distinct decreases in activity. Also, a decrease of activity was found for the more lipophilic nitrogen containing phytol analogs 110 and 111. Similar relationships were observed among the triterpenes and sterols where a free hydroxy or carbonyl at C-3 appears to be essential for high activity. For instance, compounds $\mathbf{7 2}$ and $\mathbf{7 9}$ were both more active than their corresponding C-3 acetoxy derivatives, $\mathbf{7 3}$ and $\mathbf{8 0}$, respectively.

The resurgence of infectious diseases such as drug-resistant tuberculosis necessitates more intense future efforts in the discovery of new specific drugs from natural and synthetic sources. The recent development of efficient and reproducible bioassays plays a significant role in the present and future discovery and development of new anti-TB leads. A number of compounds covered in this review possess in vitro antimycobacterial activities comparable to standard anti-TB drugs. They certainly warrant further investigations on the long path from the initial activity findings to the development of new antituberculosis drugs.

\section{Acknowledgements}

The authors are grateful to Dr. Mohamed S. Rajab from the Department of Chemistry, Moi University, Eldoret, Kenya for helpful discussions.

\section{References}

${ }^{1}$ Dye C, Scheele S, Dolin P, Pathania V, Raviglione MC. Consensus statement. Global burden of tuberculosis: estimated incidence, prevalence, and mortality by country. WHO Global Surveillance and Monitoring Project. Journal of the American Medical Association 1999; 282: 677-86

${ }^{2}$ Raviglione MC, Snider DE, Jr., Kochi A. Global epidemiology of tuberculosis. Morbidity and mortality of a worldwide epidemic. Journal of the American Medical Association 1995; 273: 220-6 
${ }^{3}$ Grassi C, Peona V. New drugs for tuberculosis. European Respiratory Journal. Supplement 1995; 20: 714s-8s

${ }^{4}$ Sepkowitz KA, Raffalli J, Riley L, Kiehn TE, Armstrong D. Tuberculosis in the AIDS era. Clinical Microbiology Reviews 1995; 8: 180-99

${ }^{5}$ Cohn DL, Bustreo F, Raviglione MC. Drug-resistant tuberculosis: review of the worldwide situation and the WHO/IUATLD Global Surveillance Project. International Union Against Tuberculosis and Lung Disease. Clinical Infectious Diseases 1997; 24: S12130

${ }^{6}$ Espinal MA, Laszlo A, Simonsen L, Boulahbal F, Kim SJ, Reniero A, Hoffner S, Rieder HL, Binkin N, Dye C, Williams R, Raviglione MC. Global trends in resistance to antituberculosis drugs. New England Journal of Medicine 2001; 344: 1294-303

${ }^{7}$ Chien HP, Yu MC, Ong TF, Lin TP, Luh KT. In vitro activity of rifabutin and rifampin against clinical isolates of Mycobacterium tuberculosis in Taiwan. Journal of the Formosan Medical Association 2000; 99: 408-11

${ }^{8}$ Yang B, Koga H, Ohno H, Ogawa K, Fukuda M, Hirakata Y, Maesaki S, Tomono K, Tashiro T, Kohno S. Relationship between antimycobacterial activities of rifampicin, rifabutin and KRM-1648 and rpoB mutations of Mycobacterium tuberculosis. Journal of Antimicrobial Chemotherapy 1998; 42: $621-8$

${ }^{9}$ Matteelli A, Olliaro P, Signorini L, Cadeo G, Scalzini A, Bonazzi L, Caligaris S, Tomasoni L, Tebaldi A, Carosi G. Tolerability of twice-weekly rifabutin-isoniazid combinations versus daily isoniazid for latent tuberculosis in HIV-infected subjects: a pilot study. International Journal of Tuberculosis and Lung Disease 1999; 3: $1043-6$

${ }^{10}$ Narita M, Stambaugh JJ, Hollender ES, Jones D, Pitchenik AE, Ashkin D. Use of rifabutin with protease inhibitors for human immunodeficiency virus-infected patients with tuberculosis. Clinical Infectious Diseases 2000; 30: 779-83

${ }^{11}$ Parola D, Dell'Orso D, Giovagnoli S, Bianconi S, Terzano C. The tolerability and therapeutic efficacy of rifabutin in the treatment of pulmonary tuberculosis. Recenti Progressi in Medicina 1999; 90: $254-7$

${ }^{12}$ Sirgel FA, Botha FJ, Parkin DP, Van De Wal BW, Donald PR, Clark PK, Mitchison DA. The early bactericidal activity of rifabutin in patients with pulmonary tuberculosis measured by sputum viable counts: a new method of drug assessment. Journal of Antimicrobial Chemotherapy 1993; 32: 867-75

${ }^{13}$ Lenaerts AM, Chase SE, Chmielewski AJ, Cynamon MH. Evaluation of rifapentine in long-term treatment regimens for tuberculosis in mice. Antimicrobial Agents and Chemotherapy 1999; 43: $2356-60$

${ }^{14}$ Tomioka H. Prospects for development of new antimycobacterial drugs, with special reference to a new benzoxazinorifamycin, KRM-1648. Archivum Immunologiae et Therapiae Experimentalis 2000; 48: $183-8$

${ }^{15}$ Maranetra KN. Quinolones and multidrug-resistant tuberculosis. Chemotherapy 1999; 45: $12-8$

${ }^{16}$ Sirgel FA, Botha FJ, Parkin DP, Van de Wal BW, Schall R, Donald PR, Mitchison DA. The early bactericidal activity of ciprofloxacin in patients with pulmonary tuberculosis. American Journal of Respiratory and Critical Care Medicine 1997; 156: 901 -5

17 Sirgel FA, Donald PR, Odhiambo J, Githui W, Umapathy KC, Paramasivan CN, Tam CM, Kam KM, Lam CW, Sole KM, Mitchison DA. A multicentre study of the early bactericidal activity of antituberculosis drugs. Journal of Antimicrobial Chemotherapy 2000; 45: $859-70$

${ }^{18}$ Yew WW, Chan CK, Chau CH, Tam CM, Leung CC, Wong PC, Lee $\mathrm{J}$. Outcomes of patients with multidrug-resistant pulmonary tuberculosis treated with ofloxacin/levofloxacin-containing regimens. Chest 2000; 117: 744-51

${ }^{19}$ Gillespie SH, Billington O. Activity of moxifloxacin against mycobacteria. Journal of Antimicrobial Chemotherapy 1999; 44: $393-5$
${ }^{20}$ Ji B, Lounis N, Maslo C, Truffot-Pernot C, Bonnafous P, Grosset J. In vitro and in vivo activities of moxifloxacin and clinafloxacin against Mycobacterium tuberculosis. Antimicrobial Agents and Chemotherapy 1998; 42: 2066-9

${ }^{21}$ Miyazaki E, Miyazaki M, Chen JM, Chaisson RE, Bishai WR. Moxifloxacin (BAY12-8039), a new 8-methoxyquinolone, is active in a mouse model of tuberculosis. Antimicrobial Agents and Chemotherapy 1999; 43: 85-9

${ }^{22}$ Cynamon MH, Klemens SP, Sharpe CA, Chase S. Activities of several novel oxazolidinones against Mycobacterium tuberculosis in a murine model. Antimicrobial Agents and Chemotherapy 1999; 43: $1189-91$

${ }^{23}$ Stover CK, Warrener P, VanDevanter DR, Sherman DR, Arain TM, Langhorne MH, Anderson SW, Towell JA, Yuan Y, McMurray DN, Kreiswirth BN, Barry CE, Baker WR. A small-molecule nitroimidazopyran drug candidate for the treatment of tuberculosis. Nature 2000; 405: 962-6

${ }^{24}$ Collins L, Franzblau SG. Microplate alamar blue assay versus BACTEC 460 system for high-throughput screening of compounds against Mycobacterium tuberculosis and Mycobacterium avium. Antimicrobial Agents and Chemotherapy 1997; 41: 1004-9

${ }^{25}$ Cantrell CL, Lu T, Fronczek FR, Fischer NH, Adams LB, Franzblau SG. Antimycobacterial cycloartanes from Borrichia frutescens. Journal of Natural Products 1996; 59: $1131-6$

${ }^{26}$ Cantrell CL. Antimycobacterial natural products from higher plants. Department of Chemistry, Baton Rouge, LA: Louisiana State University 1998: 173 pp

${ }^{27}$ Rajab MS, Cantrell CL, Franzblau SG, Fischer NH. Antimycobacterial activity of $(E)$-phytol and derivatives. A preliminary structure-activity study. Planta Medica 1998; 64: $2-4$

${ }^{28}$ Fischer NH, Lu T, Cantrell CL, Castaneda-Acosta J, Quijano L, Franzblau SG. Antimycobacterial evaluation of germacranolides. Phytochemistry 1998; 49: 559-64

${ }^{29} \mathrm{Lu}$ T, Fischer NH. Spectral data of chemical modification products of costunolide. Spectroscopy Letters 1996; 29: 437-48

${ }^{30}$ Cantrell CL, Nunez IS, Castaneda-Acosta J, Foroozesh M, Fronczek FR, Fischer NH, Franzblau SG. Antimycobacterial activities of dehydrocostus lactone and its oxidation products. Journal of Natural Products 1998; 61: 1181-6

${ }^{31}$ Cantrell CL, Abate L, Fronczek FR, Franzblau SG, Quijano L, Fischer NH. Antimycobacterial eudesmanolides from Inula helenium and Rudbeckia subtomentosa. Planta Medica 1999; 65: $351-5$

32 Ulubelen A, Topcu G, Johansson CB. Norditerpenoids and diterpenoids from Salvia multicaulis with antituberculous activity. Journal of Natural Products 1997; 60: 1275-80

33 Puyvelde LV, Ntawukiliyayo JD, Portaels F. In vitro inhibition of mycobacteria by Rwandese medicinal plants. Phytotherapy Research 1994; 8: 65-9

${ }^{34}$ Topcu G, Erenler R, Cakmak O, Johansson CB, Celik C, Chai H-B, Pezzuto JM. Diterpenes from the berries of Juniperus excelsa. Phytochemistry 1999; 50: 1195-9

${ }^{35}$ Wachter GA, Franzblau SG, Montenegro G, Suarez E, Fortunato RH, Saavedra E, Timmermann BN. A new antitubercular mulinane diterpenoid from Azorella madreporica Clos. Journal of Natural Products 1998; 61: 965-8

${ }^{36}$ Cantrell CL, Rajab MS, Franzblau SG, Fronczek FR, Fischer NH. Antimycobacterial ergosterol-5,8-endoperoxide from Ajuga remota. Planta Medica 1999; 65: $732-4$

${ }^{37}$ Cantrell CL, Rajab MS, Franzblau SG, Fischer NH. Antimycobacterial triterpenes from Melia volkensii. Journal of Natural Products 1999; 62: $546-8$

${ }^{38}$ Wachter GA, Valcic S, Flagg ML, Franzblau SG, Montenegro G, Suarez E, Timmermann BN. Antitubercular activity of pentacyclic triterpenoids from plants of Argentina and Chile. Phytomedicine 1999; 6: $341-5$ 
${ }^{39}$ Caldwell CG, Franzblau SG, Suarez E, Timmermann BN. Oleanane triterpenes from Junellia tridens. Journal of Natural Products 2000; 63: $1611-4$

${ }^{40}$ Heifets LB, Cynamon MH. Drug susceptibility in the chemotherapy of mycobacterial infections. Boca Raton, Fla: CRC Press, 1991

${ }^{41}$ Fischer NH, Mabry TJ. New pseudoguianolides from Ambrosis confertiflora. Tetrahedron 1967; 23: 2529-38

${ }^{42}$ Geissman TA, Matsueda S. Sesquiterpene lactones. Constituents of diploid and polyploid Ambrosia dumosa. Phytochemistry 1968; 7: 1613-21

${ }^{43}$ Quijano L, Gomez-Garibay F, Trejo-B RI, Rios T. Hydroxy-bis-dihydroencelin, a dimeric eudesmanolide and other eudesmanolides from Montanoa speciosa. Phytochemistry 1991; 30: 3293-5

${ }^{44}$ Vasquez M, Quijano L, Urbatsch LE, Fischer NH. Sesquiterpene lactones and other constituents from Rudbeckia mollis. Phytochemistry $1992 ; 31: 2051-4$

${ }^{45}$ Quijano L, Calderon JS, Federico Gomez G, Jesus Lopez P, Rios T, Fronczek FR. The crystal structure of 6-epi-deacetyllaurenobiolide, a germacra-1(10),4-diene-12,8-alpha-olide from Montanoa grandiflora. Phytochemistry 1984; 23: $1971-4$

${ }^{46}$ von Daehne W, Godtfredsen WO, Rasmussen PR. Structure-activity relationships in fusidic acid-type antibiotics. Advances in Applied Microbiology 1979; 25: 95-146

${ }^{47}$ Osterberg T, Norinder U. Prediction of drug transport processes using simple parameters and PLS statistics. The use of ACD/logP and ACD/ChemSketch descriptors. European Journal of Pharmaceutical Science 2001; 12: 327-37

\section{Dr. Charles L. Cantrell}

USDA, ARS

National Center for Agricultural Utilization Research 1815 North University Street

Peoria

Illinois 61604

U.S.A.

E-mail: cantrellc@mail.ncaur.usda.gov

Fax: +1-309-681-6686

Tel.: +1-309-681-6349 